\title{
Micro Family Businesses in the Czech Republic from the Perspective of Multiple Criteria Decision- Making
}

\author{
Vojtěch Meier ${ }^{1, *}$
}

${ }^{1}$ Faculty of Economics, Department of Management, Sokolská tř́́da 33, 702000 Ostrava, Czech Republic

\begin{abstract}
.
Research background: Family businesses are undoubtedly important in both the Czech and international economy. They also play a crucial part in globalization. They have always been providing the largest job source in the private sector all over the world. However, over all these years, there has not been a unified definition of family business, which makes the government hard to distinguish between family and non - family business. Thus, this complicated the administrative and legal process. Finally, in 2019, the definition of the family business in the Czech Republic has been specified, which has facilitated many administrative and legal processes. Simultaneously, the management of Czech family businesses is currently facing the first "post-revolutionary" transition of generations. Many family businesses are deciding whether to maintain or to change the type of business entities.

Purpose of the article: This article aims to determine the most advantageous legal form of business for micro family businesses.

Methods: This article uses the Saaty pair comparison method and TOPSIS method. In addition to the methods of analysis, synthesis, and comparison, the selected methods of multiple criteria decision making are used in the article.

Findings \& Value added: The results of the decision analysis revealed that, based on the criteria considered (legal, accounting, tax and managerial), the most optimal legal form of the family business is self-employed. Apart from the results, the research adds value to this topic for the Czech business environment, in which future scholars can compare between the Czech Republic and the other countries.
\end{abstract}

Keywords: Family business; succession; Multiple criteria decision-making; Saaty's method; TOPSIS.

JEL Classification: $M 10 ; M 41 ; H 20 ; K 20$

\footnotetext{
${ }^{1}$ Corresponding author: vojtech.meier@,vsb.cz
} 


\section{Introduction}

Family businesses are the main business influencers in both developing and developed economies. Family businesses dominate world trade and generate 70-90\% of GDP. According to the latest statistical data, they create $50-80 \%$ of jobs worldwide. In Europe, family businesses are even more important as [1] claimed. They represented $70 \%$ of the gross domestic product. Moreover, they also contribute to economic growth in South and East Asia, Latin America and Africa [2].

Their impact on business environment can be expected to be growing in the near future. In recent years, the first generation of family businesses in the Czech Republic have to think about the transitioning to the next generation. According to [3], the most problematic phase of family business is the transfer from the first to the second generation. Inevitably, succession planning will be a topical issue among family business, as has been acknowledged by studies from [4]. [5] has proven that succession processes heavily influenced the whole performance, such as a change in the debt rate. In contrast with family business, traditional companies may face a large staff turnover mainly due to mutual ignorance of employees especially in the turbulent environment.

The relationship between company performance and succession plan of family business was studied by [6]. The sample base is from the Italian companies and [6] compared the businesses which run by the heir of the founders with the businesses which managed by outsiders. They concluded that maintaining family management negatively affects business performance. The impact is more significant especially in competitive business sectors. The results suggest that there is no inherent supremacy of the family business structure and emphasizes the importance of conducting management analysis under different institutional conditions.

Family business has a long tradition in the Czech Republic and is without doubt an integral part of the national economy. Not only micro enterprises but also small and medium sized businesses used to play a significant role in the Czech economy and politics [7]. Unfortunately, the family business era was interrupted by the centrally planned economy in the Czech Republic. Family businesses were disappearing in the Czech Republic until 1989. After the Velvet Revolution, the family business boomed again due to the transformation of the centrally planned economy into the market - oriented economy. As a result, many family businesses have begun to put their efforts into business again [8].

The main aim of this study is to determine which of the possible variants of family firms that differ in the legal form of business is the most advantageous for the micro family enterprises by using the chosen multiple criteria decision-making method (Saaty and TOPSIS).

The structure of this paper is as follows. Section 2 presents the findings from the related literature; Section 3 includes the methods that has been used in this study; Section 4 discusses the methodology of our research; Section 5 presents the analysis and evaluation of this study; Section 6 concludes this study; Section 7 states the acknowledgement.

\section{Literature review}

The definition of "family business" gives great importance to the business environment. It helps family businesses to identify laws that related to them, so the management team from the family businesses can respond quickly and flexibly on laws without unnecessary bureaucracy. With the confusion in what family business really is in the previous decades, finally in May 2019, a definition of "family business" has been introduced to the Czech Republic [9]. It is possible to statistically and realistically evaluate the impact of family businesses of the economy. It also launches structural changes, such as the possibilities of tax relief or value added tax rates changes that have influence on prices of products and services [10].

Not only do family businesses contribute to the economies across the whole world, but they also create quality workplace. On the other hand, their lack of sustainability might worth to be 
concerned. It has been estimated that only $30 \%$ of family businesses survive to the second generation, while even fewer than $14 \%$ make it to the third generation [11].

According to [12] one of the main reasons for the relatively high failure rate on family business is because of the inability of family businesses to be prepared on succession process.

The transfer of management and CEO from the current generation to the next generation in a family business usually takes several years. Successors are often associated with the company since childhood - they help, participate, see and hear what is being solved in the company [13]. If the company provides more opportunities for the successors to grow, these younger generations can usually bring new wind and new projects such as opening e-shops, adopting another approach to marketing, using of social networks and etc. They can take the family business further.

[14] found a higher equity ratio, family businesses have higher ability to survive difficult

periods of recession and stagnation. This fundamentally supports the stability of the overall economy. They can quickly adapt to changes in the economic and social environment and play a vital role in regional development, creating lasting ties with employees, customers, suppliers, and local communities. Family businesses show a high degree of honesty. They embrace corporate social responsibility and actively deals with environmental and sustainability issues [28].

Contrarily, [15] emphasized that the older generation can provide experiences and knowledge, but recognizing the new ways of business or opportunities must be done by the new generation. This might be an issue as [16] claimed and suggested that family business with notable prosperity should hire non-family managers.

\section{Used methods}

The article uses multiple criteria decision making methods - specifically for the weighting of the Saaty method's criteria. The TOPSIS method was used to determine the optimal variation. In addition to these methods, methods of description, analysis, synthesis and comparison are used as well.

\subsection{Saaty Pair Comparison Method}

Saaty's method is one of the most commonly used methods for determing weights [17]. Firstly, the pairs of criteria are always compared and the rating is stored in the so-called Saaty matrix S $=\left(\mathrm{S}_{\mathrm{ij}}\right)$. Secondly, the size of the preference is determined. Size of the preference is expressed by a certain number of points from selected point scale with descriptors. Thus, Saaty method differs from the pairwise comparison method, which compares preferential direction.

Use (1) to determine the weight of criteria $v_{i}$,

$$
v_{i}=\frac{G_{i}}{\sum_{i=1}^{n} G_{i}},
$$

where $G_{I}$ is the geometric mean of the $i$-th criterion. The relevance of evaluating the weight of the criteria is verified by the consistency factor $C R$ determined (2),

$$
C R=\frac{C I}{R I} \text {, }
$$

where $R I$ is random index. $C I$ is the consistency index determined by (3),

$$
C I=\frac{\lambda, \max -N}{N-1}
$$

where $\lambda_{\max }$ is the largest matrix's own number and $N$ number of criteria. $\lambda_{\max }$ is determined by $(4)$,

$$
\lambda_{\max }=\frac{1}{N} \sum_{i}^{N}(S . w)_{i} / w_{i},
$$

where $N$ is the number of criteria, $w$ is a vector and $S . w$ is the $i$-th element of vector. 


\subsection{TOPSIS Method}

TOPSIS is a technique for order preference by similarity to an ideal solution from the negativeideal solution. It was proposed and studied by two co-authors [18]. Recently, several studies have focused on the TOPSIS method and applied it in many fields such as financial performance evaluation and company evaluation or even business administration. [19] defined TOPSIS as a method based on selection of variants that are closest to the so-called ideal variant. It is characterized by a vector of the best criterion values and at the same time farthest from the socalled basal variant. The basic variant is the variant whose characteristic is defined by the vector of the worst critical values. TOPSIS method contains the following steps:

Elements of matrix $y_{i j}$ are transformed to the values of the $\mathrm{r}_{\mathrm{ij}}$ according to (5),

$$
r_{i j}=\frac{y_{i j}}{\left(\sum_{i=1}^{n} y_{i j}^{2}\right)^{1 / 2}}
$$

Calculate the elements of the weighted criterion matrix $\mathrm{W}=\left(\mathrm{w}_{\mathrm{ij}}\right)$ as $\mathrm{w}_{\mathrm{ij}}=\mathrm{v}_{\mathrm{j}} \mathrm{r}_{\mathrm{ij}}$ where $\mathrm{v}_{\mathrm{j}}$ is the weight of $i$-th criterion.

From the elements of the matrix $\mathrm{W}$, the ideal variant with critical values is determined $\left(\mathrm{H}_{1}\right.$, $\left.\mathrm{H}_{2}, \ldots \mathrm{H}_{\mathrm{k}}\right)$ and basal variant with values $\left(\mathrm{D}_{1}, \mathrm{D}_{2}, \ldots \mathrm{D}_{\mathrm{k}}\right)$, where $\mathrm{H}_{\mathrm{j}}=\max \left(\mathrm{w}_{\mathrm{ij}}\right)$ and $\mathrm{D}_{\mathrm{j}}=\min _{\mathrm{i}}\left(\mathrm{w}_{\mathrm{ij}}\right), \mathrm{j}$ $=1,2, \ldots \mathrm{k}$.

The distance of the variants from the ideal and basal variants is calculated according to (6) and (7),

$$
\begin{aligned}
& d_{i}^{+}=\left[\sum_{i=1}^{k}\left(w_{i j}-H_{j}\right)^{2}\right]^{1 / 2} \\
& d_{i}^{+}=\left[\sum_{i=1}^{k}\left(w_{i j}-D_{j}\right)^{2}\right]^{1 / 2}
\end{aligned}
$$

Calculate $c_{\mathrm{i}}(8)$ as the relative distance of the variants from the basal variants:

$$
c_{i}=\frac{d_{i}^{-}}{d_{i}^{-}+d_{i}^{+}}
$$

Values ci are form the interval $<0.1>$. they have values of 0 for basal variation and 1 for ideal variant. Variants can therefore be arranged according to decreasing values of indicator ci.

\section{Input Data}

The study was carried out between January 2019 and April 2019. With the aid of Family Business Association in the Czech Republic, data on micro family businesses (i.e. number of employees < 9) is obtained for this study [20].

The absence of a clear definition of family business means that there is currently no data on the exact number of family businesses in the Czech Republic. As mentioned above, the research was conducted in the Moravian-Silesian region, where, in 2019 has a total of 30,975 industrial companies. This figure is therefore considered to be the size of the sample base.

To determine the sample size, formula (9) is used

$$
n=\frac{z^{2} \cdot N \cdot r(1-r)}{\left(d^{2} \cdot N\right)+\left[z^{2} \cdot r(1-r)\right]}
$$

where $N$ is size of base population, $z$ is coefficient of confidence, $d$ is tolerance rate and $r$ expected deviation rate. The input values were determined according to the methodological instructions and recommendations from the Auditors chamber of the Czech Republic. The number of respondents in questionnaire survey is 31 micro companies.

$$
n=\frac{1,96^{2} \cdot 30975.0,02(1-0,02)}{\left(0,05^{2} \cdot 30975\right)+\left[1,65^{2} .0,02(1-0,02)\right]}=31
$$




\subsection{Evaluation of Criteria}

When assessing the advantages of different legal forms of family businesses, legal, accounting, tax and managerial criteria are considered. In total, five different options are distinguished by the legal form of business.

$-\mathrm{V}_{1}$ - Family businesses in the legal form of self-employed

- $V_{2}$ - Family businesses - legal entity in legal form of joint-stock company

$-\mathrm{V}_{3}$ - Family businesses - legal entity in legal form of limited liability company

- $\mathrm{V}_{4}$ - Family businesses - legal entity in legal form of limited partnership

- $\mathrm{V}_{5}$ - Family businesses - legal entity in legal form of public company

As mentioned above, choosing the optimal variant affects in total four groups of criteria. The first set is legal criteria $\left(\mathrm{K}_{1}\right)$. The basis for assessing $j$-th variant, taking into account $i$-th criterion, is legislation such as the Civil Code or Commercial Corporation. Self-employed businesses are more advantageous than other business entities because the process of setting up is easier than the other entities. On the other hand, setting up a joint-stock company is the most complicated among all entities as [21] stated.

The second set being considered is the accounting criteria $\left(\mathrm{K}_{2}\right)$. The self-employed person is allowed to keep tax evidence if he/she does not exceed the turnover determined by the Accounting Act for the accounting period. Compared with bookkeeping, tax evidence is less demanding [22]. For legal entities it is mandatory that they must keep accounting as [23] claims.

Taking into account the tax aspect of decision making is ensured by criterion $\mathrm{K}_{3}$. For tax aspect, tax burden is represented by an income tax - personal or corporate according to the legal form of business. The tax aspects do not evaluate the nominal tax rate. Nominal tax rate usually doesn't represent real tax burden. For this reason is necessary to use effective tax rate [24].

Last group of four compared is a group that focuses on managerial aspects $\left(\mathrm{K}_{4}\right)$. Managerial aspects are attributed the same weight as all mentioned criteria. From this point of view, attention was focused especially on the assumption of family and non-family members for the performance of managerial functions in family businesses as well as interest degree of family members and non-family members in the context of ownership/co-ownership share in family business [25]. In this case, the author keeps the same rating for all four groups of legal entities. A summary of the evaluation results of $i$-th criteria is presented in Tab. 1 .

Table 1. Matrix of absolute utility

\begin{tabular}{|c|c|c|c|c|c|c|}
\hline & $\mathbf{V}_{\mathbf{1}}$ & $\mathbf{V}_{\mathbf{2}}$ & $\mathbf{V}_{\mathbf{3}}$ & $\mathbf{V}_{\mathbf{4}}$ & $\mathbf{V}_{\mathbf{5}}$ & Type \\
\hline $\mathrm{K}_{1}$ & 1 & 5 & 3 & 3 & 3 & MIN \\
\hline $\mathrm{K}_{2}$ & 1 & 5 & 4 & 4 & 4 & MIN \\
\hline $\mathrm{K}_{3}$ & 1 & 4 & 4 & 3 & 2 & MIN \\
\hline $\mathrm{K}_{4}$ & 1 & 3 & 3 & 3 & 3 & MIN \\
\hline
\end{tabular}

\section{Analysis and Evaluation of Variants}

In the introduction, weighting of criteria was determined by using (1). From the results presented in Tab. 2 is clear that $\mathrm{K}_{4}$ criterion - managerial aspects obtained the highest weight. The lowest weight has criteria $\mathrm{K}_{2}$ and $\mathrm{K}_{3}$ assesses accounting and tax aspect of business. 
Table 2. Consistency verification

\begin{tabular}{|c|c|c|c|c|c|c|c|}
\hline & $\mathbf{K}_{\mathbf{1}}$ & $\mathbf{K}_{\mathbf{2}}$ & $\mathbf{K}_{\mathbf{3}}$ & $\mathbf{K}_{\mathbf{4}}$ & $\mathbf{g}_{\mathbf{i}}$ & $\mathbf{v}_{\mathbf{i}}$ & $\mathbf{C R}$ \\
\hline $\mathrm{K}_{1}$ & 1 & 3 & 3 & $1 / 3$ & 1,316 & 0,277 & 0,078 \\
\hline $\mathrm{K}_{2}$ & $1 / 3$ & 1 & 1 & $1 / 3$ & 0,577 & 0,121 & 0,028 \\
\hline $\mathrm{K}_{3}$ & $1 / 3$ & 1 & 1 & $1 / 3$ & 0,577 & 0,121 & 0,028 \\
\hline $\mathrm{K}_{4}$ & 3 & 3 & 3 & 1 & 2,279 & 0,479 & 0,094 \\
\hline & & & & & 4,750 & 1 & \\
\hline
\end{tabular}

Formula (2) verifies consistency of the data. Since the CR index in all cases are less than 0.1 , the data in the matrix is consistent.

Evaluation of the variants is shown in Tab. 3. For best option, it is typical that the value $c_{i}(8)$ should be as high as possible. This condition is fulfilled in variant $\mathrm{V}_{1}$ - when family business is in a legal form of self-employed person. On the other hand, from the point of view of the considered criteria, joint stock company is the least favorable in micro family business, which is $\mathrm{V}_{2}$. The remaining variants $\mathrm{V}_{3}, \mathrm{~V}_{4}$ and $\mathrm{V}_{5}$ acquire similar values of $\mathrm{c}_{\mathrm{i}}$.

Legal forms of public companies, limited partnership and limited liability companies achieved similar results. The reason is because the same absolute utility for $\mathrm{K}_{1}, \mathrm{~K}_{2}$ and $\mathrm{K}_{4}$ criteria considered. With the lowest tax burden and lower constraints of legal acts, setting up a business in the legal form of the self-employed is the reason why variant $\mathrm{V}_{1}$ gets in the index of value 1 and thus is the best among the set of business entities.

Table 3. TOPSIS Method

\begin{tabular}{|c|c|c|c|c|c|c|c|}
\hline & $\mathbf{K}_{\mathbf{1}}$ & $\mathbf{K}_{\mathbf{2}}$ & $\mathbf{K}_{\mathbf{3}}$ & $\mathbf{K}_{\mathbf{4}}$ & $\mathbf{d i}+$ & $\mathbf{d i}-$ & $\mathbf{c}_{\mathbf{i}}$ \\
\hline $\mathrm{V}_{1}$ & 0,038 & 0,014 & 0,017 & 0,078 & 0 & 0,232 & $\mathbf{1}$ \\
\hline $\mathrm{V}_{2}$ & 0,190 & 0,070 & 0,068 & 0,236 & 0,170 & 0 & $\mathbf{0}$ \\
\hline $\mathrm{V}_{3}$ & 0,114 & 0,056 & 0,051 & 0,236 & 0,254 & 0,079 & $\mathbf{0 , 2 3 7}$ \\
\hline $\mathrm{V}_{4}$ & 0,114 & 0,056 & 0,051 & 0,236 & 0,254 & 0,079 & $\mathbf{0 , 2 3 7}$ \\
\hline $\mathrm{V}_{5}$ & 0,114 & 0,056 & 0,068 & 0,236 & 0,257 & 0,077 & $\mathbf{0 , 2 3 1}$ \\
\hline Ideal & 0,038 & 0,014 & 0,017 & 0,078 & & & \\
\hline Bazal & 0,190 & 0,070 & 0,068 & 0,236 & & & \\
\hline
\end{tabular}

\section{Conclusion}

The purpose of the article was to evaluate variants of different legal business form by using multiple criteria decision making method (TOPSIS and Saaty). Considered that the weight of criteria was different and significantly influenced by resulting order of variants, the result shows that running a self-employment business is the best for micro family enterprises; the least advantageous variant is a joint-stock company.

From a managerial perspective, the research was primarily about assessing performance of managerial functions in family businesses as well as the degree of involvement of family and non-family workers in leading positions. In all types of businesses, management criteria have been assigned the same number of importance because the authority and performance of managerial functions are equally important for family businesses in self-employed form as well as those of others. In each type of businesses, the role of manager is key and contributes to its 
proper operation, regardless of the size of the enterprise. For family businesses, it is clear that family members will be more interested than non-family members.

This article was prepared as a part of the SGS project at the Faculty of Economics, VŠB-TU Ostrava, project number: SP2019/7.

\section{References}

1. Pindado, J., Requejo, I., de la Torre, C. (2012). Do family firms use dividend policy as a governance mechanism? Evidence from the Euro Zone. Corporate Governance: An International Review, 20(5), 413-431.

2. Saenz González, J., García-Meca, E. (2014). Does corporate governance influence earnings management in latin american markets? Journal of Business Ethics, 121(3), 419-440.

3. Villalonga, B., Amit, R. (2006). How do family ownership, control and management affect firm value? Journal of financial Economics, 80(2), 385-417.

4. Bennedsen, M., Nielsen, K. M., Pérez-González, F., Wolfenzon, D. (2007). Inside the family firm: the role of families in succession decisions and performance. The Quarterly Journal of Economics, 122(2), 647-691.

5. De Almeida, Diniz Camargos, M., Goulard, L. (2018). Family-owned businesses and familybusiness dynamics. Qualitative research, 3(33), 64-83.

6. Fang, H., Kotlar, J., Memili, E., Chrisman, J. J., De Massis, A. (2018). The pursuit of international opportunities in family firms: Generational differences and the role of knowledge- based resources. Global Strategy Journal, 8(1), 136-157.

7. Vilčeková, L., Mucha, B., Peracek, T. (2018). Selected issues of family business in selected countries with emphasis on the Slovak Republic. Proceedings of the 31st International Business Information Management Association Conference (pp. 129-138). Milan, Italy, April $26-28,2018$.

8. Evropský parlament 2015, Usnesení Evropského parlamentu ze dne 8. září 2015 o rodinných podnicích v Evropě (2014/221(INI).

9. Kalls, S., and Probst, S. (2013) Familienunternehmen: gesellschafts- und zivilrechtliche Fragen. Wien: Manzsche Verlags.

10. Chua, J. H., Chrisman, J. J., Steier, L. P., Rau, S. B. (2012). Sources of heterogeneity in family firms: an introduction. Entrepreneurship Theory and Practice, 36(6), 1103-1113.

11. Labelle, R., Hafsi, T., Francoeur, C., Amar, W. B. (2018). Family firms' corporate social performance: A calculated quest for socioemotional wealth. Journal of Business Ethics, 148(3), 511-525.

12. De Massis, A., Frattini, F., Majocchi, A., Piscitello, L. (2018). Family firms in the global economy: Toward a deeper understanding of internationalization determinants, processes, and outcomes. Global Strategy Journal, 8(1), 3-21.

13. Chua, J. H., Chrisman, J. J., De Massis, A., Wang, H. (2018). Reflections on family firm goals and the assessment of performance. Journal of Family Business Strategy, 9(2), 107113.

14. Samara, G., Jamali, D., Sierra, V., Parada, M. J. (2018). Who are the best performers? The environmental social performance of family firms. Journal of Family Business Strategy, 9(1), 33-43. 
15. Arzubiaga, U., Iturralde, T., Maseda, A., Kotlar, J. (2018). Entrepreneurial orientation and firm performance in family SMEs: the moderating effects of family, women, and strategic involvement in the board of directors. International Entrepreneurship and Management Journal, 14(1), 217-244.

16. Molly, V., Uhlaner, L. M., De Massis, A., Laveren, E. (2019). Family-centered goals, family board representation, and debt financing. Small Business Economics, 53(1), 269-286.

17. Saaty, T. L., Vargas, L. G. (1998). Diagnosis with dependent symptoms: bayestheorem and the analytic hierarchy process. Operational Research, 46(4), 491-502.

18. Hwang, Ching-L, Lai, Young-J., Ting-Yun L. (1993). A New Approach for Multiple Objective Decision Making. Computers and Operational Research, 20(8), 889-899.

19. Junior, F. R. L., Osiro, L., Carpinetti, L. C. R. (2014). A comparison between fuzzy AHP and fuzzy TOPSIS methods to supplier selection. Applied Soft Computing, 21, 194-209.

20. Machek, O. (2017). Rodinné firmy. C. H. Beck, Praha.

21. Urbano, D., Aparicio, S., Audretsch, D. (2019). Twenty-five years of research on institutions, entrepreneurship, and economic growth: what has been learned?. Small Business Economics, 53(1), 21-49.

22. Krzikallová, K., Tosenovsky, F. (2020). Is the value added tax system sustainable? the case of the Czech and Slovak Republics. Sustainability, 12(12), 4925.

23. González, M., Guzman, A., Pablo, E., Trujillo, M. A. (2020). Does gender really matter in the boardroom? Evidence from closely held family firms. Review of Managerial Science, 14(1), 221-267.

24. Krajnak, M. (2019). Do selected tax advantages affect tax revenue from the personal income tax? Journal of Competitiveness, 11(4), 73-88.

25. Molly, V., Uhlaner, L. M., De Massis, A., Laveren, E. (2019). Family-centered goals, family board representation, and debt financing. Small business economics, 53(1), 269-286. 